\title{
Comparative Biomass and Water Status of Four Range Grasses Grown under Two Soil Water Conditions
}

\author{
HEMA PANDE AND J.S. SINGH
}

\begin{abstract}
The influence of water stress on growth of four grasses was investigated. Panicum coloratum and Chloris gayana, the two $\mathrm{C}_{4}$ species, were more adversely affected, while the two $\mathrm{C}_{3}$ species (Poa pratensis and Lolium perenne) were found to tolerate the water stress conditions better as reflected by a comparatively smaller decline in their biomass.
\end{abstract}

Water stress develops in a plant when the rate of transpiration exceeds the rate of water uptake in transport through the plant (Kozlowski 1968). The effect of water stress has been studied in numerous plants with the indication that under such conditions the growth is usually retarded (Mott and McComb 1975, Gerakis et al. 1975, Etherington 1967, etc.). According to De Puit and Cald well (1975), water stress reduces plant growth by decreasing net assimilation. It has also been noted that $C_{3}$ and $C_{4}$ plants respond differentially to water stress. Many $\mathrm{C}_{4}$ plants (e.g., Zea Mays) (Boyer 1970) are found to be more severely affected by drought than $C_{3}$ plants although they have many characteristics which enable them to adapt effectively under stress. On the other hand, many $C_{3}$ species such as Poa pratensis (Carrol 1943), can withstand water stress rather effectively.

The purpose of this study was to obtain information on the influence of water stress on growth of four range grasses. Out of these four grasses, Poa pratensis L. (Kentucky bluegrass) and Lolium perenne L. (Perennial rye grass) have $\mathrm{C}_{3}$ pathway of photosynthesis and the other two, Chloris gayana (Kunth (Rhodesgrass) and Panicum coloratum L. (Makarakeri grass), possess the $\mathrm{C}_{4}$ photosynthetic pathway. While the first two species grow naturally in the temperate Himalaya, the latter two are being tested for introduction in this area to augment the forage supply.

\section{Material and Methods}

\section{Plant Material}

Tillers of Poa pratensis and Lolium perenne were collected in the beginning of July, 1977 , from a native sward at Naini Tal $\left(29^{\circ} 24^{\prime}\right.$ N.lat. and $79^{\circ} 28^{\prime}$ E. long., 2,050 m altitude), while those of Chloris gayana and Panicum coloratum were obtained from the farm of Indo-German Agricultural Development Association (IGADA) at Almora $(67 \mathrm{~km}$ north of Naini Tal). Within each species the tillers were of uniform size. The tillers were transplanted into polyethylene pots filled with a weighed amount of a mixture of soil and farmyard manure (3:1) and grown under glasshouse conditions at Naini Tal from July to November, 1977. Temperature in the glasshouse ranged between $11^{\circ} \mathrm{C}$ (minimum) and $32^{\circ} \mathrm{C}$ (maximum) during the experimental period.

\section{Soil Water Conditions}

The water-holding capacity of the pot mixture was determined (Piper 1966) before the start of the experiment and after tiller

The authors are, respectively, lecturer and reader in botany, Kumaun University, Naini Tal 263002, India.

Manuscript received January 3, 1980. transplantation. For the first 2 weeks, the pots were watered regularly to bring the soil water to the level of maximum waterholding capacity. After this period soil water content in one set of pots for each species was maintained at full water holding capacity (1 WHC) while in the other set the soil was allowed to dry to a level as close as possible to half water-holding capacity $(1 / 2 \mathrm{WHC})$. Under both conditions pots were weighed every 3rd or 4th day and soil water was brought to the desired level (i.e., 1 WHC and $1 / 2$ WHC). Also, soil water content was monitored gravimetrically at frequent intervals. For each species 72 pots were maintained under 1 WHC and 72 pots under $1 / 2$ WHC. There was small variation in water content within each set as exemplified by data in Table 1 .

Table 1. Percent soil water content on November 9, 1977.

\begin{tabular}{lcc}
\hline \hline & \multicolumn{2}{c}{ Treatment } \\
\cline { 2 - 3 } Species & 1 WHC & $1 / 2$ WHC \\
\hline Poa pratensis & $45 \pm 1.60$ & $25 \pm 1.10$ \\
Lolium perenne & $42 \pm 1.60$ & $25 \pm 1.60$ \\
Panicum coloratum & $46 \pm 1.60$ & $21 \pm 1.70$ \\
Chloris gayana & $43 \pm 1.10$ & $23 \pm 0.80$ \\
\hline
\end{tabular}

\section{Plant Water Status}

The relationship between the initial and turgid water content has been expressed in various forms, such as water saturation deficit (WSD) (Oppenheimer and Mendel 1939) and relative turgidity (Weatherly 1950) or relative water content (RWC) (Ehlig and Gardner 1964; Slatyer and Barrs 1965). The term relative turgidity has been frequently used but it is an unsuitable term, as the measured value by no means expresses turgor (Slavik 1974). However, since both WSD and RWC are related with each other (WSD $=100-\mathrm{RWC}$ ), determination of one of them is sufficient to express the plant water status. For the determination of WSD, the last fully emerged leaf in each case was sampled, weighed, immersed in distilled water for $2 \frac{1}{2}-3$ hours, again weighed, oven dried, and reweighed. The following expression was used:

Water saturation $=$ Saturated weight-original deficit $(\%)$

$$
\frac{\text { fresh weight }}{\text { Saturated weight-oven dry weight }} \times 100
$$

The absolute water content before saturation (WCBS) and after saturation (WCAS) was calculated on per gram dry weight basis.

Before excising the leaves the apparent width and thickness at the midpoint of each leaf was measured to determine leaf rolling index (LRI)' ${ }^{1}$ The expression used for the calculation of LRI was:

$$
\text { LRI }=\frac{\text { Apparent thickness of leaf }(\mathrm{mm})}{\text { Apparent width of leaf }(\mathrm{mm})}
$$

Redmann, R.E. 1973. Plant water relationships. Tech. Rep. No. 29. Canadian Commission for IBP. Matador Proj., Univ. Saskatchewan. 84 p. 
The total number of leaf samples for all the above determinations were 9,9 ( 1 WHC, $1 / 2$ WHC) for Poa pratensis; 10,14 ( $1 \mathrm{WHC}, 1 / 2 \mathrm{WHC}$ ) for Lolium perenne; 11,12 (1 WHC, $1 / 2$ WHC) for Panicum coloratum and 6,6 (WHC, $1 / 2$ WHC) for Chloris gayana.

\section{Pigment Concentration}

On the same date when leaf water status was determined, leaf samples from three plants under each treatment were collected from each plot for chlorophyll estimation. The outline of these leaf samples were drawn on a paper to determine leaf area, using a planimeter. Each leaf sample was then divided in two halves, one of which was used to determine dry weight, while the other was used for chlorophyll determination. Chlorophyll was extracted in $80 \%$ acetone and the optical density (OD) was read at $630,645,652$, and $665 \mathrm{~nm}$ in a spectrophotometer. The expressions given by Arnon (1949) were used for the calculation of pigment concentration:

$$
\begin{aligned}
& \text { Total Chl }(\mathrm{a}+\mathrm{b}),(\mathrm{mg} / \mathrm{l})=\frac{\mathrm{OD}_{652} \times 1000}{34.5} \\
& \text { Chl a }(\mathrm{mg} / \mathrm{l})=15.6 \mathrm{OD}_{665}-2.0 \mathrm{OD}_{645}-0.8 \mathrm{OD}_{630} \\
& \text { Chl b }(\mathrm{mg} / \mathrm{l})=\text { Total } \mathrm{Chl}-\mathrm{Chl} \mathrm{a}
\end{aligned}
$$

\section{Plant Biomass}

The rest of the plant material, from which leaves were sampled for chlorophyll, was then carefully removed, washed, scparated into component parts (leaves, stem, and roots), oven dried at $80^{\circ} \mathrm{C}$, and weighed. The weight of the material used for chlorophyll determination was added to the leaf weight.

\section{Total Leaf Area and Specific Leaf Area}

The specific leaf area was calculated by dividing the leaf area by leaf dry weight (as determined above, see pigment concentration). The specific leaf area was multiplied by the total leaf dry weight to obtain total leaf area per plant.

The degree of succulence was calculated using the following expression:

$\begin{aligned} & \text { Degree of } \\ & \text { succulence }\end{aligned}=\frac{\begin{array}{c}\text { Water content at } \\ \text { saturation }(\mathrm{g})\end{array}}{\text { Surface area }\left(\mathrm{cm}^{2}\right)}$

The data reported in this paper were collected in November, 1977, when the experiment was terminated.

\section{Results and Discussion}

Both shoot and root dry weights were lower in plants under $1 / 2$ WHC compared to the 1 WHC condition (Table 2). The decline in the plant biomass was greatest for Panicum followed by Chloris and Poa. Lolium showed the least reduction in total biomass. Several authors have reported a reduction in the dry matter yield of grasses caused by water stress (Mott and McComb 1975, Gerakis et

\begin{tabular}{|c|c|c|c|c|}
\hline Species & $\begin{array}{l}\text { Total shoot } \\
\text { dry weight } \\
\text { (g/plant) }\end{array}$ & $\begin{array}{l}\text { Total root } \\
\text { dry weight } \\
\text { (g/plant) }\end{array}$ & $\begin{array}{c}\text { Total plant } \\
\text { dry weight } \\
\text { (g/plant) }\end{array}$ & $\begin{array}{c}\text { Root } / \text { shoot } \\
\text { ratio }\end{array}$ \\
\hline \multicolumn{5}{|c|}{ Poa pratensis } \\
\hline $1 \mathrm{WHC}$ & $2.1 \pm 0.03$ & $1.4 \pm 0$ & $3.5 \pm 0.03$ & $0.6 \pm 0.01$ \\
\hline $1 / 2$ WHC & $1.5 \pm 0.03$ & $0.6 \pm 0.06$ & $2.1 \pm 0.03$ & $0.04 \pm 0.06$ \\
\hline \multicolumn{5}{|c|}{ Lolium perenne } \\
\hline 1 WHC & $2.3 \pm 0.03$ & $1.9 \pm 0.50$ & $4.2 \pm 0.50$ & $0.8 \pm 0.20$ \\
\hline $1 / 2$ WHC & $2.2 \pm 0.10$ & $1.6 \pm 0.30$ & $3.8 \pm 0.40$ & $0.7 \pm 0.01$ \\
\hline \multicolumn{5}{|c|}{ Panicum coloratum } \\
\hline 1 WHC & $7.4 \pm 0.80$ & $2.4 \pm 0.70$ & $9.8 \pm 1.40$ & $0.3 \pm 0.10$ \\
\hline $1 / 2$ WHC & $4.0 \pm 0.30$ & $1.1 \pm 0.90$ & $5.1 \pm 0.40$ & $0.3 \pm 0.03$ \\
\hline \multicolumn{5}{|c|}{ Chloris gayana } \\
\hline I WHC & $6.1 \pm 0.30$ & $0.9 \pm 0.30$ & $7.0 \pm 0.10$ & $0.14 \pm 0.10$ \\
\hline $1 / 2$ WHC & $3.3 \pm 0.20$ & $0.9 \pm 0.3$ & $4.2 \pm 0.30$ & $0.30 \pm 0.10$ \\
\hline
\end{tabular}
al. 1975). This decrease is evidently due to a decline in net

Table 2. Effect of water stress on dry matter yield of four grasses. assimilation brought about by decreased water potentials in the leaves (De Puit and Caldwell 1975). Kozlowski (1964, 1968), Slatyer (1967), Crafts (1968), and Kramer (1969) have also reported that a decrease in turgor due to water stress influences cell expansion, which in turn causes reduction in photosynthesis. The effect of water stress on the yield may be accentuated since the rate of decline of photosynthesis may be more rapid than that of respiration under water stress (Kramer 1969, Levitt 1972). In certain situations water stress coupled with high temperature may even cause an increase in respiration rate thus depressing the net assimilation further (Hellmuth 1968, Troughton and Cowan 1968, and Dunn 1970). Etherington (1967) found that even very slight water deficits reduced photosynthesis in Alopecurus pratensis considerably. That the adverse effect of water stress on growth is variable for different species and depends on their relative drought tolerance has been shown by various authors (Mott and McComb 1975, Gerakis et al. 1975).

The relative decrease in shoot and root dry weights was different in different species. The water stress caused a severe reduction in the shoot dry weight of the two $\mathrm{C}_{4}$ species (about $50 \%$ ), while in $P o a$ and Lolium the reduction was negligible. This would indicate that the two $C_{3}$ species are more resistant to water stress; Carrol (1943) also found Poa pratensis to be one of the most droughttolerant species out of several pasture grasses test. Boyer (1970) found that photosynthesis in Glycine hispida was not reduced until leaf water potential dropped below -11 bars, while photosynthesis of corn was affected a nywhere below -3.5 bars. Therefore, Z. mays, which has a $\mathrm{C}_{4}$ pathway, is more sensitive to desiccation.

Reduction in the root dry weight was greatest for Poa $(58 \%)$ followed by Panicum (53\%) and Lolium (18\%). In fact, in Lolium the root dry weight under $1 / 2$ WHC was considerably higher on all sampling dates before the final harvest for which data are reported in this paper. On the other hand, the water stress had no influence on the root weight of Chloris. Only a slight, or no, decrease in root weight may be due to some stimulation of root growth by slight moisture stress. This has also been reported for certain other species (Eaton 1942, Jarvis 1963).

There was a decline in the root/shoot ratio due to water stress in Poa and Lolium, while in the case of $\mathrm{C}_{4}$ plants either the root/shoot ratio increased (Chloris) or remained unchanged (Panicum). Several authors have reported an increase in root/shoot ratios of plants growing under water stress (Peters and Runkles 1967, Black 1968). According to Loomis et al. (1971) the water stress slows shoot growth more and sooner than it does root growth. The root/shoot behaviour of Poa and Lolium did not conform to the above findings (e.g., Fig. la,b). Gerakis ct al. (1975) in Bromus, and Williams and Shapter (1955) in many graminaceous species also showed a decrease in root/shoot ratio with increasing water stress. Evidently, within limits, an increase in

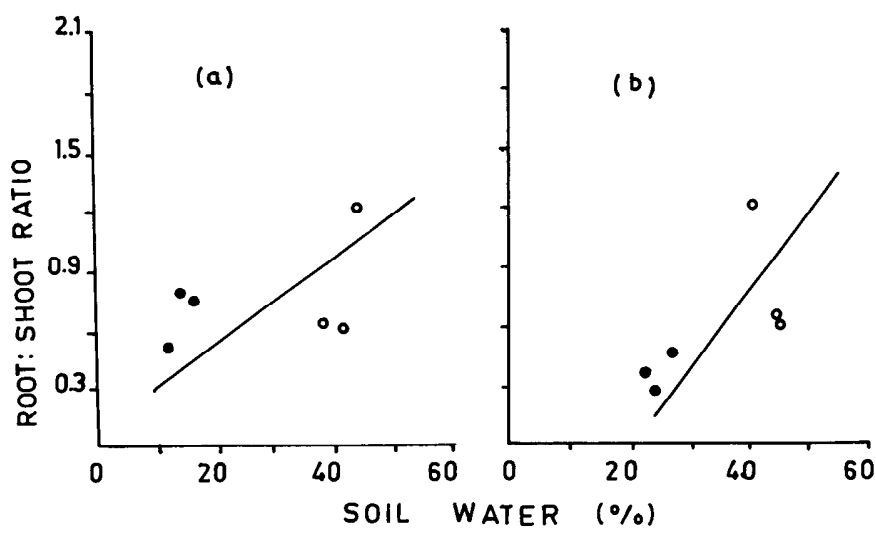

Fig. 1. Root: shoot ratio of Lolium perenne (a), and Poa pratensis (b) at different soil water conditions. Solid circles represent plants grown near $1 / 2$ WHC and open circles represent plants grown near 1 WHC. In this and other figures, curves are fitted by eye. 
Table 3. Leaf area and pigment concentration (mean $\pm 1 \mathrm{SE}$ ) in four grasses grown under two soil watering conditions.

\begin{tabular}{|c|c|c|c|c|c|}
\hline \multirow[b]{2}{*}{ Species } & \multirow[b]{2}{*}{ Specific leaf area $\left(\mathrm{cm}^{2}\right)$} & \multirow[b]{2}{*}{ Total leaf area $\left(\mathrm{cm}^{2}\right)$} & \multicolumn{3}{|c|}{ Chlorophyll (mg/g dry weight) } \\
\hline & & & Chl a & $\mathrm{Chl} \mathrm{b}$ & Total Chl \\
\hline \multicolumn{6}{|l|}{ Poa pratensis } \\
\hline I WHC & $439.90 \pm$ & $697.60 \pm 138.50$ & $1.03 \pm 0.04$ & $0.68 \pm 0.09$ & $1.70 \pm 0.11$ \\
\hline $1 / 2$ WHC & $513.30 \pm 66.10$ & $611.30 \pm 111.80$ & $1.31 \pm 0.11$ & $1.54 \pm 0.15$ & $2.86 \pm 0.26$ \\
\hline \multicolumn{6}{|c|}{ Lolium perenne } \\
\hline 1 WHC & $628.10 \pm 142.30$ & $975.0 \pm 163.50$ & $1.17 \pm 0.17$ & $0.66 \pm 0.17$ & $1.83 \pm 0.34$ \\
\hline $1 / 2$ WHC & $493.20 \pm 71.70$ & $895.80 \pm 180.20$ & $0.91 \pm 0.04$ & $0.34 \pm 0.06$ & $1.24 \pm 0.01$ \\
\hline \multicolumn{6}{|c|}{ Panicum coloratum } \\
\hline $1 \mathrm{WHC}$ & $579.80 \pm$ & $2406.50 \pm 384.40$ & $1.23 \pm 0.08$ & $1.67 \pm 0.20$ & $2.90 \pm 0.28$ \\
\hline $1 / 2$ WHC & $358.80 \pm 23.40$ & $936.60 \pm 151.80$ & $0.73 \pm 0.04$ & $0.42 \pm 0.07$ & $1.15 \pm 0.12$ \\
\hline \multicolumn{6}{|l|}{ Chloris gayana } \\
\hline 1 WHC & $202.20 \pm 30.50$ & $679.60 \pm 124.40$ & $0.41 \pm 0.07$ & $0.47 \pm 0.14$ & $0.88 \pm 0.21$ \\
\hline $1 / 2 \mathrm{WHC}$ & $323.90 \pm 39.80$ & $527.20 \pm 24.7$ & $0.30 \pm 0.01$ & $0.51 \pm 0.05$ & $0.81 \pm 0.05$ \\
\hline
\end{tabular}

Table 4. Certain plant water status parameters for four grasses grown under two soil water conditions.

\begin{tabular}{|c|c|c|c|c|c|}
\hline \multirow[b]{2}{*}{ Species } & \multicolumn{5}{|c|}{$($ Mean $\pm \mathrm{SE})$} \\
\hline & $\begin{array}{l}\text { Water content before } \\
\text { saturation }\left(\mathrm{g} \mathrm{H}_{2} \mathrm{O} / \mathrm{g}\right. \\
\text { dry weight) }\end{array}$ & $\begin{array}{l}\text { Water content after } \\
\text { saturation }\left(\mathrm{g} \mathrm{H}_{2} \mathrm{O} / \mathrm{g}\right. \\
\text { dry weight })\end{array}$ & $\begin{array}{l}\text { Water saturation } \\
\text { deficit } \\
(\%)\end{array}$ & $\begin{array}{l}\text { Water saturation deficit } \\
\text { deficit on the basis of } \\
1 \text { WHC plants }\end{array}$ & Leaf rolling index \\
\hline \multicolumn{6}{|l|}{ Poa pratensis } \\
\hline $1 \mathrm{WHC}$ & $1.7 \pm 0.15$ & $4.1 \pm 0.17$ & $42 \pm 2.2$ & - & $0.005 \pm 00$ \\
\hline $1 / 2 \mathrm{WHC}$ & $1.2 \pm 0.05$ & $4.7 \pm 0.24$ & $61 \pm 1.7$ & 70 & $0.017 \pm 0.004$ \\
\hline \multicolumn{6}{|l|}{ Lolium perenne } \\
\hline $1 \mathrm{WHC}$ & $2.6 \pm 0.29$ & $3.7 \pm 0.37$ & $29 \pm 3.2$ & - & $0.013 \pm 0.002$ \\
\hline $1 / 2 \mathrm{WHC}$ & $0.64 \pm 0.05$ & $2.2 \pm 0.20$ & $72 \pm 4.2$ & 81 & $0.017 \pm 0.001$ \\
\hline \multicolumn{6}{|c|}{ Panicum coloratum } \\
\hline I WHC & $2.1 \pm 0.10$ & $3.0 \pm 0.15$ & $29 \pm 1.6$ & - & $0.005 \pm 0.001$ \\
\hline $1 / 2 \mathrm{WHC}$ & $1.5 \pm 0.15$ & $2.7 \pm 0.27$ & $54 \pm 3.7$ & 58 & $0.009 \pm 0.002$ \\
\hline \multicolumn{6}{|l|}{ Chloris gayana } \\
\hline $1 \mathrm{WHC}$ & $1.8 \pm 0.27$ & $5.2 \pm 0.47$ & $65 \pm 4.4$ & -- & $0.005 \pm 0.001$ \\
\hline $1 / 2 \mathrm{WHC}$ & $1.7 \pm 0.10$ & $5.0 \pm 0.47$ & $65 \pm 3.2$ & 66 & $0.013 \pm 0.002$ \\
\hline
\end{tabular}

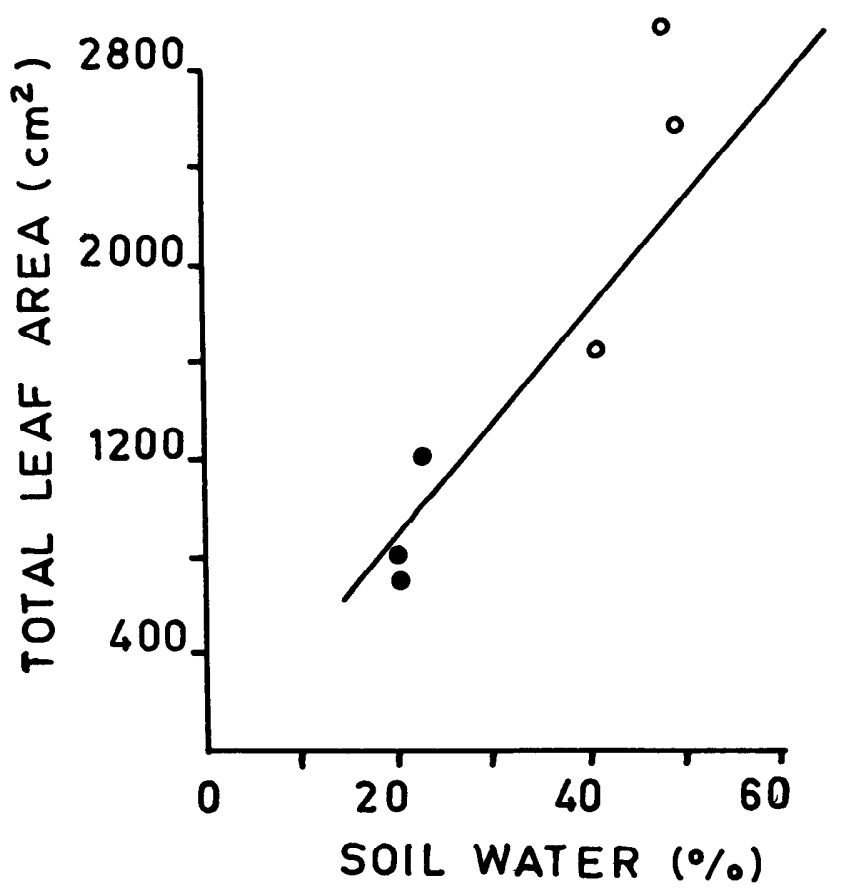

Fig. 2. Relationship between total leaf area and soil water in Panicum coloratum. Solid circles represent plants grown near $1 / 2$ WHC and open circles represent plants grown near 1 WHC.

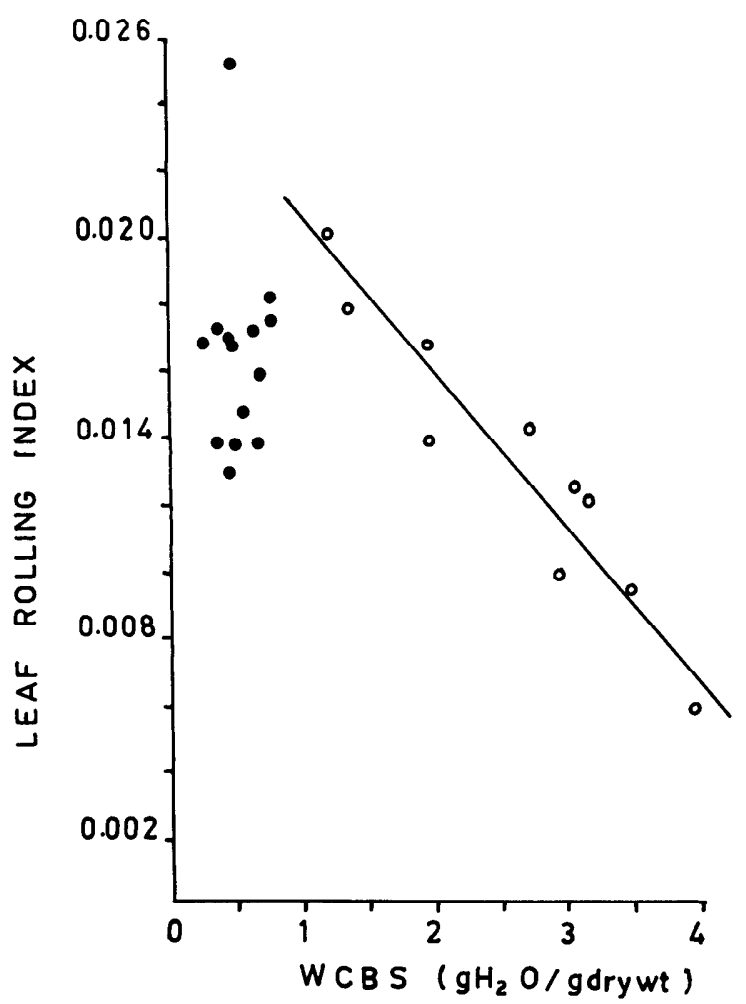

Fig. 3. Relationship between leaf rolling index and absolute water content before saturation (WCBS) in Lolium perenne. Solid circles represent plants grown near $1 / 2$ WHC and open circles represent plants grown near 1 WHC. 
the supply of water to the roots may increase both root and shoot growth, the latter to a greater extent (Troughton 1960, 1962, Wardlaw 1968; Davidson 1969, Luxmoore and Millington 1971). Both Poa and Lolium had the greatest root/shoot ratios. This characteristic is thought to be conducive to drought tolerance (Maximov 1929; Parker 1968).

The values for total leaf a rea per plant were somewhat lower in $1 / 2$ WHC plants as compared to the plants under 1 WHC; however, the effect was not significant in Poa and Lolium (Table 3). In POa and Chloris the specific leaf area in plants under $1 / 2$ WHC was greater than that in 1 WHC plants, while the reverse was true for the other two species (Table 3). The chlorophyll concentration, with the exception of Poa, was lower in plants growing under $1 / 2$ WHC. In three out of four species there appeared to be a positive relationship between total leaf area and soil water (e.g., Fig. 2). Water stress may often slow the leaf expansion even before affecting photosynthesis (Brouwer and de Wit 1969). Further, Etherington (1967) has reported that in Alopecurus pratensis the reduction of net assimilation rate conforms with the lowered photosynthesis, and the reduced leaf area ratio suggests that water stress limits full tissue expansion.

The water content before saturation (WCBS), as expected, was higher in plants of all species grown under 1 WHC (Table 4). The difference in this attribute between 1 WHC and $1 / 2$ WHC conditions was maximum in Lolium and almost negligible in Chloris. After saturation, the water content of the leaf tissue increased in all the cases but the magnitude of increase was variable. For instance, in Poa and Chloris the water content subsequent to saturation increased about four times, while in Panicum and Lolium the increase was only 1.5 to 2 times (Table 4). Consequently, the water content needed for saturation was much more in the cases of Chloris and Poa as compared to the other two species.

Although the leaf tissue from the plants grown under 1 WHC also showed a considerable amount of WSD, the latter was conspicuously magnified in the plants under $1 / 2$ WHC, with the exception of Chloris, in which the difference in WSD between the two water treatments was negligible. When the WSD in leaves under $1 / 2$ WHC was calculated relative to that of 1 WHC plants the values came out relatively higher for Poa and Lolium as compared to the two $\mathrm{C}_{4}$ species (Table 4 ).

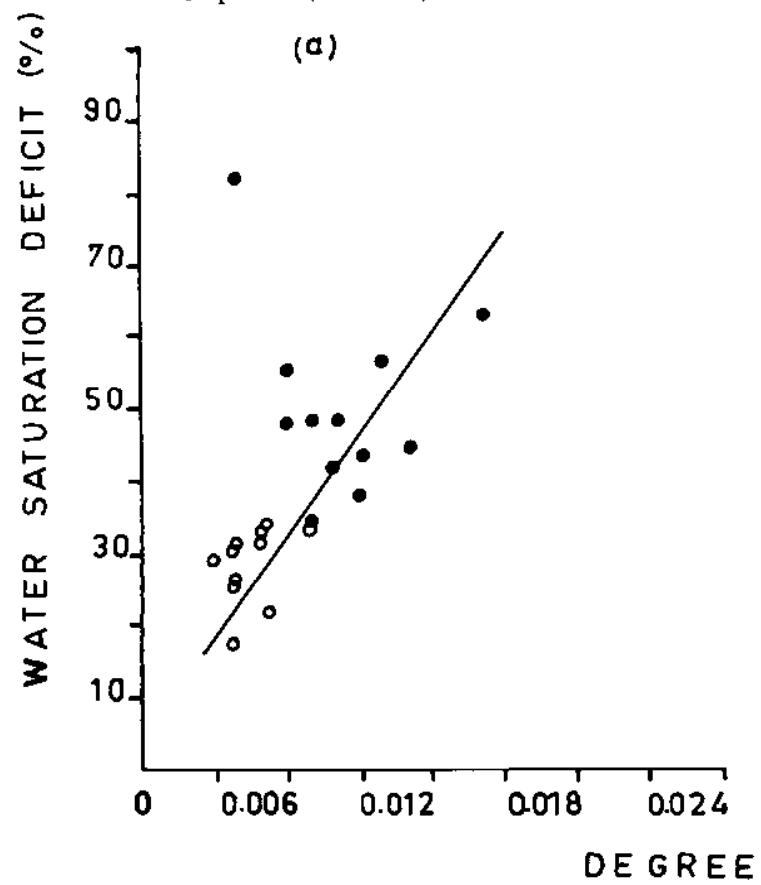

Fig. 4. Relationship between saturation deficit and degree of succulence.

(a) Panicum coloratum, solid circles represent plants grown near $1 / 2$ $W H C$ and open circles represent plants grown near I WHC.
Invariably the leaf rolling index (LRI) was higher for plants grown under $1 / 2$ WHC (Table 4). Leaves of a number of grasses show a tendency to roll in response to higher temperatures and low water availability. This reduces the radiation load on the leaves as well as increases the transfer of sensible heat (Maxwell and Redmann 1974) ${ }^{2}$. Leaf rolling is taken as an important adaptational feature for withstanding water stress and perhaps as a good index of water status of plant. Maxwell and Redmann $(1974)^{2}$, while working on the water relations of Agropyron dasystachyum, have reported that the degree to which the leaves roll a ppears to be directly related to the water potential of the tissue within the range of 0 to -35 bars. Further there existed a very significant correlation between absolute water content (=WCBS) and water potential of leaf tissue. In the present study there existed an inverse relation between leaf rolling index (LRI) and water content before saturation (WCBS). The relation was particularly marked in plants under 1 WHC of Lolium (e.g. Fig. 3); in other cases, particularly in plants under $1 / 2 \mathrm{WHC}$, this relation was not so marked indicating a good deal of variability in these two attributes from species to species.

According to Larcher (1929), the relationship between transpiring surface and water stored in the tissue is expressed by the specific leaf area and degree of succulence. Since the rate of water evaporation usually increases with increasing transpiring area, a high degree of succulence is congenial to water conservation in a leaf. In the present study maximum degree of succulence was recorded for Chloris (average 0.026) and minimum for Panicum (average 0.005 ). The water stress did not materially affect the degree of succulence. However, WSD was positively related with the degree of succulence (Fig. 4 a,b) indicating an increasing trend at water conservation with increasing water deficit. Further, there was relatively a much wider range both in degree of succulence as well as in saturation deficit for the two $C_{4}$ species (Fig. 5). The water stressed plants $(1 / 2$ WHC) did not show any clear-cut relation between LRI and degree of succulence. The plants are known to become relatively insensitive as far as their water relations are concerned under prolonged drought conditions (Slatyer 1967).

In conclusion it may be stated that in all the four plants,

${ }^{2}$ Maxwell, J. and Redmann, R.E. 1974. Water relations and growth of Agropyron dasystachyum: recovery from soil moisture stress. Matador project. Tech. Rep. No. 64. Canadian Committee for the Internat. Biol. Programme.

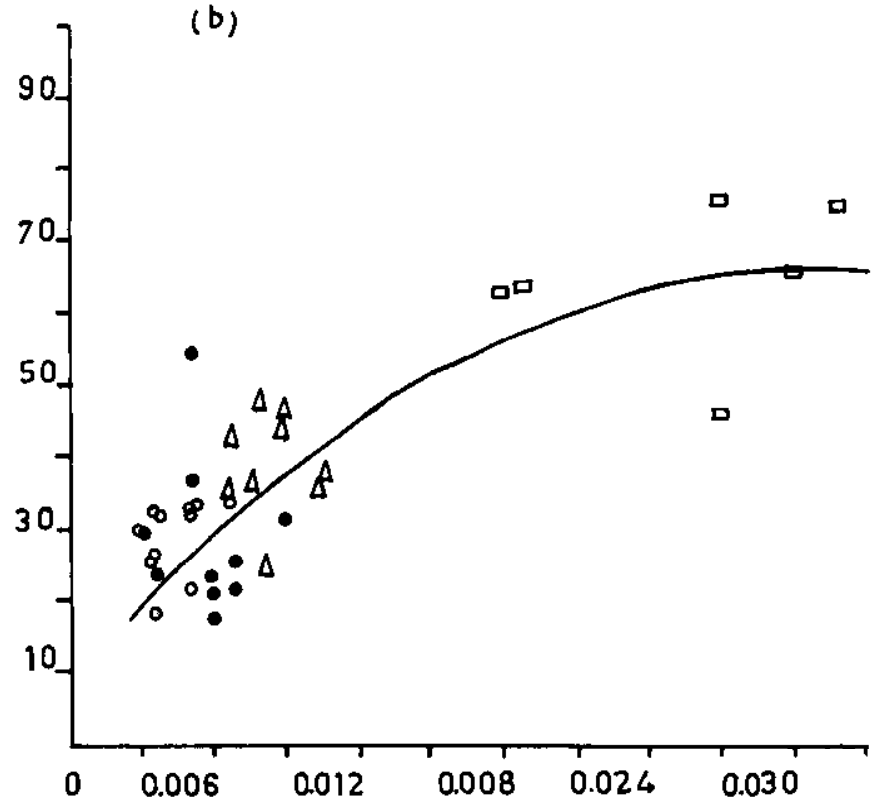

SUCCULENCE

(b) Plants grown near I WHC. Solid cirlces $=$ Lolium perenne, open circles $=$ Panicum coloratum, triangles $=$ Poa pratensis, and squares $=$ Chloris gayana. 


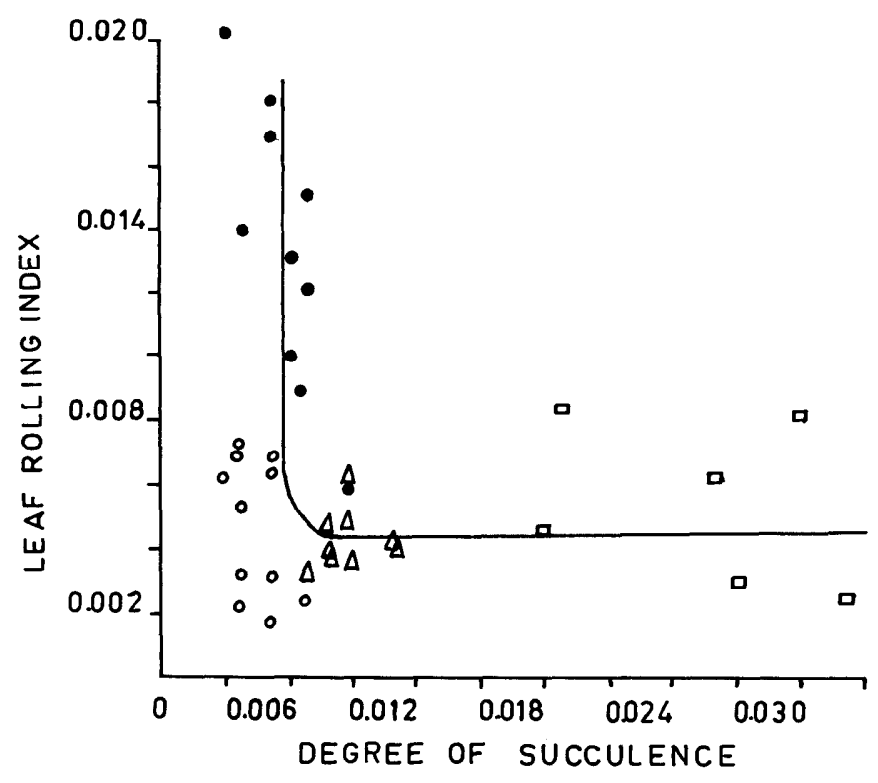

Fig. 5. Relationship between leaf rolling index and degree of succulence in plants grown near I WHC. Solid circles = Lolium perenne, open circles $=$ Panicum coloratum, triangles $=$ Poa pratensis, and squares $=$ Chloris gayana.

notwithstanding the type of photosynthetic pathway involved, water stress results in a decline in growth. Relatively there was a greater decline in the plant biomass of $\mathrm{C}_{4}$ plants (39\% Chloris, $48 \%$ Panicum) as compared to the $C_{3}$ plants ( $9 \%$ Lolium, $31 \%$ Poa). The $\mathrm{C}_{3}$ plants developed a greater amount of WSD under conditions of water stress as compared to the $\mathrm{C}_{4}$ plants, reflected comparatively a greater amount of leaf rolling and a higher root/shoot ratio. Thus the two native $C_{3}$ species were found to be better at resisting water stress compared to the two introduced $\mathrm{C}_{4}$ species. This is in contrast to the general belief that the $\mathrm{C}_{4}$ species have a greater drought resistance than $C_{3}$ species (Singh et al. 1980). Perhaps the $C_{4}$ plants possess a competitive advantage over $C_{3}$ plants only under conditions of high temperature and intermittent water stress (Doliner and Jolliffe 1979), while in a low temperature region such as as Naini Tal, the $C_{3}$ plants are better at resisting drought.

\section{Literature Cited}

Arnon, D.I. 1949. Copper enzymes in isolated chloroplasts (1) Polyphenol oxidase in Beta vulgaris. Plant Physiol. 24:1-15.

Black, C.A. 1968. Soil Plant Relationships, 2nd ed. Wiley, New York.

Boyer, J.S. 1970. Differing sensitivity of photosynthesis to low leaf water potential in corn and soybean. Plant Physiol. 46:236-239.

Bouwer, R., and C.T. de Wit. 1969. A simulation model of plant growth with special attention to root growth and its consequences. In: W.J. Whittington, (ed.). Root Growth, p. 224-44. Butterworth London.

Carrol, J.C. 1943. Effects of drought, temperature, and nitrogen on turf grasses. Pl. Physiol., Lancaster, 18:19-36.

Crafts, A.S. 1968. Water deficits and physiological processes. In: Water Deficits and Plant Growth (T.T. Kozlowski, ed.), Vol. II, Chapter 3, p. 85. Academic Press, New York.

Davidson, R.L. 1969. Effects of edaphic factors on the soluble carbohydrate contents or roots of Lolium perenne $\mathrm{L}$. and Trifolium repens L. Ann. Bot. (N.S.) 33:579-589.

DePuit, J.E., and M.M. Caldwell. 1975. Gas exchange of three cool semidesert species in relation to temperature and water stress. J. Ecol. 63:835856.

Dolliner, L.H., and P.A. Jolliffe. 1979. Ecological evidence concerning the adaptive significance of the C-4 discarboxylic acid pathway of photosynthesis. Oecologia (Berl.) 38:23-34.
Dunn, E.L. 1970. Seasonal patterns of carbondioxide metabolism in evergreen sclerophylls in California and Chile. Ph.D. Thesis, Univ. of California. Los Angeles.

Eaton, F.M. 1942. Toxicity and accumulation of chloride and sulfate salts in plants. J. Agr. Res. 64:357-99.

Ehlig, C.F., and Gardner, W.R. 1964. Relationship between the transpiration and internal water balance of plants. Agron. J. 56:127-30.

Etherington, J.R. 1967. Soil water and growth of grasses. II. Effects of soil water potential on growth and photosynthesis of Alopecurus pratensis. J. Ecol. 55:373-80.

Gerakis, P.A., Guerrero, E.P., and Williams W.A. 1975. Growth, waterrelations and nutrition of three grassland annuals as affected by drought. J. App. Ecol. 12:125-135.

Hellmuth, E.0. 1968. Ecophysiological studies on plants in arid and semiarid regions in Western Australia. I. Autecology of Rhagodia baccata. J. Ecol. 56:319-444.

Jarvis, M.S. 1963. A comparison between the water relations of species with contrasting types of geographical distribution in the British Isles. The water relations of plants In: A.J. Rutter and F.H. Whitehead (eds.) p. 289-312. Blackwell Scientific Publications, Oxford.

Kramer, P.J. 1969. Plant and Soil Water Relationship-A modern Synthesis. McGraw Hill, Ncw York.

Kozlowski, T.T. 1964. Water Metabolism in Plants. Harper, New York.

Kozlowski, T.T. 1968. Introduction. In: T.T. Kozlowski, (ed.). Water Deficits and Plant Growth, Vol. 1, p. 1. Academic Press, New York.

Larcher, W. 1929. Physiological plant ecology (Translated by M.A. Biederman-Thornson). Springer-Verlag, Berlin (1975).

Levitt, J. 1972. Responses of Plant to Environmental Stress. Academic Press New York.

Loomis, R.S., W.A. Williams, and A.D. Hall. 1971. Agricultural productivity. Annu. Rev. Plant Physiol. 22:431-68.

Iuxmoore, R.J., and R.J. Millington, 1971. Growth of perennial ryegrass in relation to water, nitrogen and light intensity 1 . Effects on leaf growth and dry weight. Plant Soil 34:269-281.

Maximov, N.A. 1929. The Plant in Relation to Water. Allen and Unwin, Lond on.

Mott, J.J., and A.J. McComb. 1975. Effects of moisture stress on the growth and reproduction of threc annual species from an arid region of Western Australia. J. Ecol. 63:825-834.

Oppenheimer, H.R., and K. Mendel. 1939. Orange leaf transpiration under orchard conditions. I. Soil moisture. high. Palestine J. Bot. 2:171-250.

Parker, J. 1968. Drought resistance mechanisms. In: T.T. Kozlowski (ed.). Water Deficits and Plant Growth. p. 195-234. Academic Press, New York.

Peters, D.B., and J.R. Runkles. 1967. Shoot and root growth as affected by water availability. In: R.M. Hagan, H.R. Haise, and T.W. Edminster (eds.). Irrigation of Agricultural Lands. p. 373-89. Amer. Soc. of Agron., Madison, Wisconsin.

Piper, C.S. 1966. Soil and Plant Analysis. Hans Publishers, Bombay.

Singh, J.S., M.J. Trlica, P.G. Risser, R.E. Redmann, and J.K. Marshall. 1980. Autotrophic subsystem. In: A.I. Breymeyer and G.M. van Dyne (ed.) Grasslands, Systems Analysis, and Man. Cambridge University Press, London, p. 59-200.

Slatyer, R.O., and H.D. Barrs. 1965. Modifications to the relative turgidity techniques with notes on its significance as an index of the internal water status of leaves. In: Methodology of Plant Ecophysiology, p. 33!-41. UNESCO, Paris.

Slatyer, R.O. 1967. Plant Water Relationships. Academic Press, New York.

Slavik, B. 1974. Methods of Studying Plant Water Relations. Acadcmia Publishing House of the Czechoslovak Academy of Sciences, Prague; Springer-Verlag, New York.

Troughton, A. 1960. Further studies on the relationship between shoot and root systems of grasses. J. Br. Grassl. Soc. 15:41-47.

Troughton, A. 1962. The roots of temperate cereals. Common W. Bur. Pastures Field Crops. Mimeo. Publ. No. 2/1962. p. 1-91.

Troughton, J.H., and I.R. Cowan. 1968. Carbondioxide exchange in cotton: Some anomalous fluctuations. Science, N.Y. 161, 281-83.

Wardlaw, I.F. 1968. The control and pattern of movement of carbohydrates in plants. Bot. Rev. 34:79-105.

Weatherly, P.E. 1950. Studies in the water relations of cotton plant. I. The field measurement of water deficits in leaves. New Phytol. 49:81-97.

Williams, R.F., and R.E. Shapter. 1955. A comparative study of growth and nutrition in barley and rye as affected by low water treatment. Aust. J. Biol. Sci. 8:435-66. 